\title{
MENINGKATKAN KEMAMPUAN BERPIKIR TINGKAT TINGGI SISWA SMA MELALUI TEKNIK PROBING - PROMTNG
}

\author{
Dewi Ananti Wulan ${ }^{1)}$, Ely Susanti ${ }^{2)}$, Nyimas Aisyah ${ }^{3)}$ \\ Program Studi Pendidikana Matematika, Universitas Swriwijaya \\ dewi.ananti13@gmail.com
}

\begin{abstract}
This research is aimed to increase students higher order thinking skill in mathematics learning using probing-prompting learning technique. This research is descriptive research with 21 students of X.C class at SMAN 02 Indralaya Utara as the subject. Learning process is according to the characteristic and steps of probing-prompting learning technique. Techniques for collecting data are test which includes of three problems and interview to obtain additional data. According to the results of research, it's obtained that representation of students' higher order thinking skill in problem based learning on X.C class at SMAN 02 Indralaya Utara is good with this details: percentage of students who have higher order thinking skill with category excellent is $19 \%$. Then, $38,1 \%$ have higher order thinking skill with category good; $28,6 \%$ have higher order thinking skill with category medium; $14,3 \%$ have higher order thinking skill with category bad; nothing shave higher order thinking skill with category very bad. Indicator of analyzing have the highest percentage with $85,7 \%$. Then, indicator of evaluating have percentage $71,4 \%$, and indicator with the lowest percentage is creating with $44,6 \%$.

Keywords: Higher order thinking skill, probing-prompting technique
\end{abstract}

Abstrak
Penelitian ini bertujuan untuk meningkatkan kemampuan berpikir tingkat tinggi
siswa pada pembelajaran matematika melalui teknik pembelajaran probing-
prompting. Penelitian ini merupakan jenis penelitian deskriptif kuantitatif dengan
subjek penelitian yaitu siswa kelas X.C SMA Negeri 2 Indralaya Utara yang
berjumlah 21 orang. Proses pembelajaran berlangsung sesuai dengan karakteristik
dan langkah-langkah teknik pembelajaran probing-prompting. Teknik
pengumpulan data yang dipakai adalah tes tertulis yang terdiri atas tiga soal dan
wawancara untuk memperoleh data tambahan. Berdasarkan hasil penelitian,
diperoleh hasil kemampuan berpikir tingkat tinggi siswa dalam pembelajaran
matematika melalui teknik probing-prompting di kelas X.C SMA Negeri 2
Indralaya Utara adalah terkategori baik dengan rincian sebagai berikut: siswa yang
memiliki kemampuan berpikir tingkat tinggi sangat baik dengan persentase sebesar
19\%. Selanjutnya, 38,1\% memiliki kemampuan berpikir tingkat tinggi dengan
kategori baik; 28,6\% memiliki kemampuan berpikir tingkat tinggi terkategori
cukup; 14,3\% memiliki kemampuan berpikir tingkat tinggi terkategori kurang; dan
tidak ada yang memiliki kemampuan berpikir tingkat tinggi dengan kategori sangat


kurang. Indikator menganalisis memiliki persentase kemunculan tertinggi yaitu sebesar $85,7 \%$. Kemudian, kemunculan pada indikator mengevaluasi adalah sebesar $71,4 \%$, dan indicator dengan persentase kemunculan terendah adalah mengkreasi yaitu sebesar $44,6 \%$.

Kata Kunci: Kemampuan berpikir tingkat tinggi, teknik probing-prompting.

\section{PENDAHULUAN}

Matematika merupakan ilmu yang diajarkan disetiap tingkatan kelas pada satuan pendidikan dasar dan menengah. Dalam pembelajaran matematika siswa diharapkan dapat mengembangkan diri dalam berfikir. Salah satu keterampilan berpikir adalah berpikir tingkat tinggi (higher order thingking). Menurut Winarso (2014) kemampuan berpikir tingkat tinggi merupakan suatu kemampuan berpikir yang tidak hanya membutuhkan kemampuan mengingat saja, namun membutuhkan kemampuan lain yang lebih tinggi, seperti kemampuan berpikir kritis dan kreatif.

Pentingnya penguasaan keterampilan berpikir tingkat tinggi terdapat dalam beberapa poin Standar Kompetensi Lulusan Sekolah Menengah. Poin yang diharapkan yaitu siswa dapat membangun dan menerapkan informasi atau pengetahuan secara logis, kritis, kreatif, dan inovatif; dapat menunjukkan kemampuan berpikir logis, kritis, kreatif, dan inovatif dalam pengambilan keputusan, serta dapat menunjukkan kemampuan menganalisis dan memecahkan masalah kompleks (Permendiknas No. 23 Tahun 2006).

Kenyataan di lapangan menunjukan bahwa belum tercapainya kemampuan berpikir tingkat tinggi dengan baik. Misalnya di SMAN 02 Indralaya Utara. Dari hasil survei dan wawancara dengan guru matematika kelas X di SMAN 02 Indralaya Utara diperoleh informasi bahwa kriteria ketuntasan minimal (KKM) untuk pelajaran matematika kelas $\mathrm{X}$ adalah 70. Pada materi trigonometri $76 \%$ siswa menunjukan tingkat berpikir yang rendah. Hal ini terlihat dari tidak tuntasnya hasil belajar siswa. Bukti lainnya yaitu ketika siswa diberikan soal yang berbeda dari contoh soal yang diberikan guru dan diberikan soal dengan level yang lebih tinggi, siswa masih kebingungan dalam mengerjakan soal tersebut. Kegiatan pembelajaran yang dilaksanakan juga belum dapat menumbuhkan kemampuan berpikir tingkat tinggi. Guru menerangkan materi pembelajaran kemudian siswa diberikan latihan soal. Hal ini mengakibatkan rendahnya aktivitas siswa sebagai pembelajar. Apabila hal ini dibiarkan akan berdampak terhadap kemampuan berpikir siswa yang rendah.

Kegiatan pembelajaran yang efektif diharapkan meningkatkan dapaat mengembangkan proses berpikir siswa. Pembelajaran keterampilan berpikir memiliki beberapa kendala. Misalnya peran guru yang sangat mendominasi di 
sekolah sebagai penebar ilmu atau sumber ilmu, menjadikan siswa sebagai sebuah tempat yang akan diisi dengan ilmu oleh guru. Masalah lain yang sesudah serig terjadi namun memang sulit diselesaikan adalah sistem evaluasi dari prestasi siswa yang lebih banyak dilaksanakan dengan menggunakan tes-tes yang pada dasarnya menguji kemampuan kognitif tingkat rendah (Sastrawati, 2011).

Oleh karena itu, perlu adanya perubahan proses belajar di kelas yang meningkatkan kemampuan pemikiran tingkat tinggi. Kemampuan berpikir tingkat tinggi ini menghendaki seseorang untuk menerapkan informasi baru atau pengetahuan sebelumnya dan memanipulasi informasi untuk menjangkau kemungkinan jawaban dalam situasi baru (Rofiah, 2013). Salah satu alternatif teknik pembelajaran yang mengupayakan siswa untuk aktif dalam membangun, memahami materi pelajaran, dan juga meningkatkan kemampuan pemikiran tingkat tinggi adalah teknik probing-prompting. Menurut Suherman (2008) teknik probing-prompting adalah pembelajaran dengan cara guru menyajikan serangkaian pertanyaan yang sifatnya menuntun dan menggali sehingga terjadi proses berpikir siswa. Siswa dibimbing menuju konsep atau teori yang diinginkan dengan menggunakan pengetahuan yang telah ada pada dirinya menjadi pengetahuan baru.

Menurut Permendiknas No. 23

Tahun 2006 diatas kemampuan berpikir kritis, kemampuan pemecahan masalah, dan kemampuan berpikir kreatif termasuk ke dalam kemampuan berpikir tingkat tinggi. Pada penelitian sebelumnya mengenai kemampuan berpikir kritis, kemampuan pemecahan masalah, dan kemampuan berpikir kreatif belum mencakup keseluruhan dari kemampuan berpikir tingkat tinggi, sedangkan pada penelitian ini kemampuan berpikir tingkat tinggi dibahas secara menyeluruh.

Berdasarkan uraian diatas penulis merasa tertarik untuk melakukan penelitian yang berjudul

"Meningkatkan

Kemampuan

Berpikir Tingkat Tinggi Siswa SMA Melalui Teknik Pembelajaran Probing-Prompting.”

Penelitian ini bertujuan meningkatkan kemampuan berpikir tingkat tinggi siswa kelas $\mathrm{X}$ dalam pembelajaran matematika melalui teknik pembelajaran probingprompting di SMAN 2 Indralaya Utara.

\section{TINJAUAN PUSTAKA}

Kemampuan berpikir tingkat tinggi didefinisikan oleh Heong (2011) sebagai suatu penggunaan pikiran secara lebih luas guna mendaptakan suatu tantangan baru. Selajutnya Heong (2011) juga mengemukakan bahwa kemampuan berpikir tingkat tinggi ini menginginkan seseorang untuk mengimplementasikan hal-hal baru atau pengetahuan sebelumnya dan mengubah informasi untuk menjangkau kemungkinan jawaban dalam situasi baru.

Menurut Rofiah

kemampuan berpikir tingkat tinggi 
yaitu proses berpikir yang berkaitan dengan aktivitas mental dalam usaha membangun pengalaman yang kompleks, reflektif, dan kreatif; yang dilaksanakan secara sadar guna mencapai tujuan, yaitu mendapatkan pengetahuan yang meliputi tingkat berpikir analitis, sintesis, dan evaluatif.

Dewanto (2014) juga mengatakan kemampuan berpikir tingkat tinggi adalah suatu kapasitas di atas informasi yang diberikan, dengan sikap yang kritis untuk mengevaluasi, mempunyai kesadaran metakognitif dan memiliki kemampuan pemecahan masalah.

Berdasarkan definisi diatas dapat disimpulkan bahwa, kemampuan berfikir tingkat tinggi adalah proses berpikir pada tingkat yang lebih tinggi daripada sekedar menghafal yang mencakup kemampuan berfikir kritis, kemampuan berfikir kreatif, dan kemampuan pemecahan masalah, serta penggunaan pikiran secara lebih luas untuk menghubungkan suatu tantangan baru dengan informasi yang sudah tersimpan di dalam ingatannya lalu memberikan kesimpulansehingga menemukan suatu penyelesaian dari suatu masalah yang sulit dipecahkan.

Kemampuan berpikir tingkat tinggi diukur menggunakan ranah dalam Taxonomi Bloom, seperti yang diungkap oleh Krathwohl (2002) bahwa indikator untuk mengukur kemampuan berfikir tinggi meliputi menganalisis, mengevaluasi, dan mengkreasi.
Dalam penelitian ini indikator yang digunakan dalam penelitian ini yaitu:

1. Menganalisis

Deskriptor: mampu menjabarkan informasi, merumuskan masalah, dan menentukan langkah penyelesaian dengan tepat.

2. Mengevaluasi

Deskriptor: mampu memberi penilaian yaitu dukungan atau menyangkal suatu gagasan, member argumentasi yang memperkuat jawaban.

\section{Mengkreasi}

Deskriptor: mampu memberikan hipotesis/ide awal, merancang strategi untuk menyelesaikan masalah, dan menciptakan suatu penyelesaian.

Menurut Suherman (2008) teknik Pembelajaran probingprompting adalah pembelajaran menggunakan serangkaian pertanyaan yang sifatnya melacak dan menuntun yang disajikan oleh guru sehingga setiap siswa dapat melatih proses berpikir yang mengaitkan pengetahuan lama dan pengalamannya dengan pengetahuan baru yang sedang dipelajari.

Sugito dan Nurani (2003) mengemukakan bahwa Prompting question yaitu pertanyaan yang diajukan untuk memberi arah kepada siswa dalam proses berpikir. Sedangkan, probing question yaitu pertanyaan lanjutan yang mendorong untuk lebih memperluas dan memperdalam jawaban yang telah 
diberikannya terhadap pertanyaan yang petama.

Dari uraian diatas disimpulkan bahwa teknik probing-prompting adalah pembelajaran dengan cara guru menyajikan serangkaian petanyaan yang sifatnya menggali dan menuntun sehingga terjadi proses berpikir yang mengaitkan pengetahuan siswa dan pengalamannya dengan pengetahuan baru yang sedang dipelajari.
Selanjutnya pengetahuan baru tidak diberitahukan sebelumnya, sehingga siswa membangun konsep-prinsipaturan menjadi pengetahuan baru. Pelaksanaan proses tanya jawab pada pembelajaran ini yaitu dengan menunjuk siswa secara acak sehingga setiap siswa harus terlibat aktif dan tidak bisa menghindar dari proses pembelajaran.

Tabel 1

Hubungan Kemampuan Berpikir Tingkat Tinggi dengan Teknik Pembelajaran Probing-Prompting

\begin{tabular}{|l|c|}
\hline \multicolumn{1}{|c|}{ Langkah-langkah Metode Pembelajaran Probing- } & $\begin{array}{c}\text { Indikator } \\
\text { Kemampuan Berpikir } \\
\text { Tingkat Tinggi }\end{array}$ \\
\hline $\begin{array}{l}\text { 1. Guru menghadapkan siswa pada situasi baru, } \\
\text { misalkan dengan memperhatikan gambar, rumus, } \\
\text { atau situasi lainnya yang mengandung }\end{array}$ & Menganalisis \\
permasalahan. & \\
2. Memberikan kesempatan kepada siswa untuk & \\
melakukan pengamatan. & \\
3. Mengajukan pertanyaan yang menuntun siswa \\
(prompting-question).
\end{tabular}




\begin{tabular}{|l|c|}
\hline $\begin{array}{c}\text { Langkah-langkah Metode Pembelajaran Probing- } \\
\text { Prompting }\end{array}$ & $\begin{array}{c}\text { Indikator } \\
\text { Kemampuan Berpikir } \\
\text { Tingkat Tinggi }\end{array}$ \\
\hline Lalu dilanjutkan dengan pertanyaan yang menuntut & \\
siswa berpikir pada tingkat yang lebih tinggi, sampai \\
dapat menjawab pertanyaan sesuai dengan \\
kompetensi dasar atau indikator. \\
9. Mengajukan pertanyaan akhir pada siswa yang \\
berbeda untuk lebih menekankan bahwa indikator \\
tersebut benar-benar telah dipahami oleh seluruh \\
siswa.
\end{tabular}

\section{METODOLOGI PENELITIAN}

Penelitian ini merupakan penelitian deskriptif kuantitatif. Dalam Penelitian, peneliti akan mendeskripsikan peningkatan kemampuan berpikir tingkat tinggi siswa kelas $\mathrm{X}$ dalam pembelajaran matematika menggunakan teknik pembelajaran probing-prompting di SMAN 2 Indralaya Utara.

Variabel dalam penelitian ini adalah kemampuan berpikir tingkat tinggi siswa kelas $\mathrm{X}$ dalam pembelajaran matematika.

Kemampuan berpikir tingkat tinggi siswa dalam penelitian ini adalah kemampuan siswa untuk menganalisis, mengevaluasi, dan mengkreasi.

Kemampuan tersebut dinilai dengan menggunakan skor yang diperoleh siswa melalui soal tes berpikir tingkat tinggi. Subjek dalam penelitian ini adalah siswa kelas X.C SMAN 2 Indralaya Utara yang berjumlah 21 siswa. Dalam penelitian ini, data dikumpulkan melalui tes tertulis dan wawancara.

Tes yang diberikan merupakan tes tertulis bentuk uraian. Tes ini terdiri dari tiga buah soal yang harus dijawab siswa mengenai kompetensi dasar dan indicator kemampuan berpikir tingkat tinggi siswa terkait materi aturan sinus dan aturan cosinus.

Wawancara dilakukan untuk memperoleh data tambahan. Subjek wawancara adalah masing-masing satu orang siswa dari tiap kategori level berpikir tingkat tinggi, yaitu satu siswa dengan kategori sangat baik, seorang siswa dengan kategori baik, seorang siswa dengan kategori cukup, dan seorang siswa dengan kategori kurang.

Setelah tes dilaksanakan, maka didapatlah skor masing-masing siswa. Skor tersebut dijumlahkan lalu dianalisis. Langkah untuk menganalsisis data hasil tes tertulis adalah menentukan nilai tes siswa dan menentukan kategori berpikir tingkat tinggi siswa. 
Tabel 2

Kategori Kemampuan Berpikir Tingkat Tinggi Siswa

\begin{tabular}{|c|c|}
\hline Nilai siswa & Kategori penilaian \\
\hline $81-100$ & Sangat baik \\
\hline $61-80$ & Baik \\
\hline $41-60$ & Cukup \\
\hline $21-40$ & Kurang \\
\hline $0-20$ & Sangat kurang \\
\hline
\end{tabular}

(Berdasarkan Internasional Center For The Assesment Of Higher Order Thingking).

Data yang diperoleh dari hasil wawancara dianalisis dengan langkah mengubah hasil wawancara dari bentuk lisan ke bentuk tulisan dan kemudian menganalisis jawaban hasil wawancara.

\section{HASIL \\ DAN \\ PEMBAHASAN}

Penelitian ini dilaksanakan mulai tanggal 6 April 2017 hingga 18 April 2017 di kelas X.C SMAN 2 Indralaya Utara. Penelitian dilaksanakan sebanyak 3 pertemuan (6 jam pelajaran) dengan dua pertemuan untuk kegiatan pembelajaran dan satu pertemuan terakhir untuk tes kemampuan berpikir tingkat tinggi.

Pembelajaran dilaksanakan sesuai dengan langkah-langkah teknik probing-prompting. Data mengenai kemampuan berpikir tingkat tinggi siswa diperoleh dari hasil tes dengan menggunakan tipe soal berpikir tingkat tinggi. Tes dilaksanakan pada pertemuan terakhir yaitu pertemuan ketiga. Pada saat pelaksanaan tes, jumlah siswa yang hadir sebanyak 21 orang. Tes dikerjakan oleh siswa secara individu. Penskoran yang dilakukan adalah sesuai dengan rubrik penskoran yang telah dibuat. Masingmasing indikator terdiri atas satu deskriptor.

Skor maksimal per deskriptor adalah empat dan skor minimumnya adalah nol. Soal pertama terdiri atas dua pertanyaan. Pertanyaan pertama mengacu pada indikator kedua dan pertanyaan yang kedua mengacu pada indikator ketiga. Skor maksimal untuk soal pertama adalah delapan. Soal kedua terdiri atas satu pertanyaan. Pertanyaan mengacu pada indikator pertama. Skor maksimal untuk soal kedua adalah empat dan skor minimumnya adalah nol. Soal ketiga terdiri atas dua pertanyaan. Pertanyaan pertama mengacu pada indikator kedua dan pertanyaan yang kedua mengacu pada indikator ketiga. Skor maksimal untuk soal pertama adalah delapan. Total skor maksimal seluruh soal adalah 20 .

Setelah semua jawaban siswa diperiksa dan diberikan skor sesuai rubrik penskoran, maka langkah selanjutnya adalah menjumlahkan skor yang diperoleh dari ketiga soal tersebut lalu dibagi dengan skor maksimal yaitu 20, kemudian dikalikan 100. Setelah diperoleh nilai 
siswa, selanjutnya nilai tersebut dikelompokkan ke dalam lima tinggi yang dapat dilihat pada Tabel 3 kategori kemampuan berpikir tingkat

di bawah ini

Tabel 3

Nilai Kemampuan Berpikir Tingkat Tinggi

\begin{tabular}{|c|c|c|c|}
\hline Nilai & Kategori & Frekuensi & Persentase (\%) \\
\hline $81-100$ & Sangat Baik & 4 & 19.0 \\
\hline $61-80$ & Baik & 8 & 38,1 \\
\hline $41-60$ & Cukup & 6 & 28,6 \\
\hline $21-40$ & Kurang & 3 & 14,3 \\
\hline $0-20$ & Sangat Kurang & 0 & 0 \\
\hline \multicolumn{2}{|}{ JUMLAH } & 21 & 100 \\
\hline \multicolumn{2}{|c|}{ Rata-rata } & $\mathbf{6 3 , 8}$ & Baik \\
\hline
\end{tabular}

Siswa terkategori sangat baik mampu menjabarkan informasi, merumuskan masalah, dan menentukan langkah penyelesaian dengan tepat. Lalu mampu memberikan penilaian dari pertanyaan dengan memberikan argumentasi dan penyelesaian yang memperkuat jawaban dalam mengevaluasi suatu gagasan dengan tepat. Selanjutnya untuk indikator mengkreasi siswa mampu memberikan hipotesis/ide awal, merancang strategi dan mengkreasi penyelesaian dengan tepat. Selain itu siswa yang terkategori baik telah mampu menganalisis dengan tepat sama seperti siswa terkategori sangat baik. Namun pada indikator mengevaluasi masih kurang mendetail dan tidak disertai dengan memberikan penilaian berupa dukungan atau menyangkal suatu gagasan. Dan untuk indikator mengkreasi siswa sudah memberikan ide awal dan juga penyelesaian dengan tepat.

Saat pembelajaran melalui teknik probing-prompting siswa dihadapkan pada hal baru, yaitu diperlihatkan gambar dan menceritakan sebuah masalah yang Selanjutnya siswa terketgori cukup telah mampu menganalisis dan mengevaluasi namun siswa masih lemah pada indikator mengkreasi. Siswa terkategori cukup belum mampu menjawab soal pada indikator mengkreasi. Begitupun juga dengan siswa terketgori kurang juga mampu menganalisis namun terkadang masih salah dalam perhitungan, mampu mengevaluasi namun belum mampu memberikan penilaian berupa dukungan atau menyangkal suatu gagasan, dan masih lemah pada indikator mengkreasi.

Secara keseluruhan rata-rata kemampuan berpikir tingkat tinggi siswa setelah pembelajaran matematika melalui teknik probingprompting pada materi aturan sinus dan cosinus adalah 63,8 dengan kategori baik. Kemudian, untuk melihat persentase kemunculan indikator kemampuan berpikir tingkat tinggi dari jawaban siswa terhadap soal tes dapat dilihat pada Tabel 4 di bawah ini. 
Tabel 4

Persentase Kemunculan Indikator Kemampuan Berpiki Tingkat Tinggi

\begin{tabular}{|l|c|}
\hline \multicolumn{1}{|c|}{ Indikator } & Persentase Kemunculan (\%) \\
\hline Menganalisis permasalahan & 85,7 \\
\hline Mengevaluasi gagasan & 71,4 \\
\hline Mengkreasi penyelesaian & 44,6 \\
\hline
\end{tabular}

Dalam menjawab pertanyaanpertanyaan pada LKS siswa diberikan pertanyaan-pertanyaan penuntun (prompting-question). Dalam hal ini diarahkan untuk melatih kemampuan menganalisinya. Hal ini sejalan dengan pendapat Rofiah (2013) bahwa suatu proses yang melibatkan aktivitas mental dalam usaha mengeksplorasi pengalaman dapat digunakan untuk memperoleh pengetahuan yang meliputi berpikir analitis.

Siswa juga diberikan pertanyaan pelacak oleh untuk melihat pemahaman siswa terhadap permasalahan. Dalam hal ini siswa diarahkan untuk melatih kemampuan memberikan alasan-alasan untuk setiap jawabannya yang merupakan indikator kemampuan mengevaluasi seperti yang diungkap karthwol (2002) bahwa kemampuan mengevaluasi meliputi memberikan penilaian berupa dukungan atau menyangkal, dan memberikan argumen yang menguatkan jawaban.

Siswa diberikan pertanyaan dengan level yang lebih tinggi, yaitu pertanyaan yang menuntut siswa untuk mengkreasi jawaban/penyelesaian. Hal ini sejalan dengan pendapat Suherman (2008) bahwa dalam pembelajaran melalui teknik probing-prompting siswa diberikan pertanyaan dengan level lebih tinggi untuk mengetahui pemahaman siswa terhadap konsep yang sedang dipelajari.

Berdasarkan hasil analisis data tes kemampuan berpikir tingkat tinggi siswa setelah pembelajaran matematika melalui teknik probingprompting pada materi aturan sinus dan cosinus terkategori baik dengan rata-rata 63,8. Siswa-siswa yang mendapatkan nilai yang terkategori baik dalam berpikir tingkat tinggi sudah dapat menjawab soal tes dengan tepat.

Terlihat pada indikator menganalisis permasalahan terlihat dari penyelesaian yang ditulis siswa, yaitu mampu menjabarkan informasi, merumuskan masalah, dan menentukan langkah penyelesaian dengan tepat. Indikator mengevaluasi siswa mampu memberikan argumentasi yang memperkuat jawaban dengan tepat, namun belum mampu memberikan penilaian berupa dukungan atau menyangkal suatu gagasan. Indikator mengkreasi telihat siswa dapat menganalisis permasalahan dengan tepat, memberikan ide awal/hipotesis, mampu merancang suatu cara yang tepat, serta menciptakan suatu penyelesaian. 
Padahal pada saat diwawancarai salah satu siswa yang terkategori baik dapat menjelaskan dengan detail jawabannya dan mampu memberikan penilaian berupa dukungan atau menyangkal suatu gagasan. Siswa yang terkategori baik dalam berpikir tingkat tinggi merupakan siswa yang terlibat aktif saat pembelajaran. Mereka mampu menjawab pertanyaan-pertanyaan yang diajukan peneliti pada saat pembelajaran dan aktif dalam menyampaikan idenya. Hal ini sejalan dengan yang dikemukakan oleh Shoimin (2014) bahwa teknik pembelajaran probing prompting mengembangkan keberanian dan keterampilan siswa dalam menjawab dan mengemukakan pendapat dan pertanyaan dapat menarik dan memusatkan perhatian siswa.

Hasil wawancara dengan salah satu siswa yang terkategori baik mengenai kaitan antara pembelajaran dengan pelaksanaan tes bahwa pembelajaran yaitu dapat membuat siswa tersebut bisa memahami masalah dalam soal tes, dan menggunakan konsep aturan sinus dan cosinus dalam menyelesaikannya.

Berdasarkan hasil analisis data tes kemampuan berpikir tingkat tinggi siswa terlihat sebesar $42,9 \%$ siswa berada dalam kategori cukup dan kurang dalam berpikir tingkat tinggi. Dengan rincian $6(28,6 \%)$ siswa dengan kategori cukup dalam berpikir tingkat tinggi dan $3(14,3 \%)$ siswa dengan kategori kurang dalam berpikir tingkat tinggi.
Siswa-siswa

yang mendapatkan nilai yang terkategori cukup dan kurang dalam berpikir tingkat tinggi sudah dapat menjawab soal tes namun masih terdapat kekurangan dalam menjawabnya.

Indikator menganalisis permasalahan terlihat dari penyelesaian yang ditulis siswa, yaitu mampu menjabarkan informasi, merumuskan masalah, dan menentukan langkah penyelesaian dengan tepat namun masih ada kekeliruan dalam proses perhitungan.

Indikator mengevaluasi siswa mampu memberikan penyelesaian, namun terkadang kurang dalam menuliskan penilaiannya berupa dukungan atau menyangkal suatu gagasan dengan tepat.

Indikator mengkreasi telihat siswa terkategori cukup dan kurang masih lemah. Pada saat diwawancarai pun salah satu siswa yang terkategori cukup dan kurang masih sering keliru dalam mengevaluasi dan masih sulit dalam menyelesaikan soal indikator mengkreasi penyelesaian.

Siswa terkategori cukup dan kurang dalam berpikir tingkat tinggi dikarenakan masih belum terbiasa memberikan penilaian berupa dukungan atau menyangkal suatu gagasan dan masih lemah dalam mengkreasi penyelesaian. Padahal dalam kemampuan berpikir tingkat tinggi siswa dituntut untuk dapat memberikan penilaian dan mengkreasi suatu penyelesaian yang merupakan merupakan indikator kemampuan mengevaluasi dan mengkreasi seperti yang diungkap karthwol (2002) bahwa 
dalam kemampuan berpikir tingkat tinggi terdapat tiga indikator yaitu menganalisis, mengevaluasi, dan mengkreasi.

Secara keseluruhan, berdasarkan hasil tes dan wawancara diperoleh bahwa rata-rata kemampuan berpikir tingkat tinggi siswa setelah dilaksankannya pembelajaran matematika melalui teknik pembelajaran probing-prompting pada materi aturan sinus dan cosinus adalah 63,8 dengan kategori "baik". Dengan begitu teknik pembelajaran probingprompting dapat dijadikan salah satu teknik pembelajaran dalam pembelajaran matematika.

\section{KESIMPULAN DAN SARAN Kesimpulan}

Berdasarkan hasil penelitian di kelas X.C SMA Negeri 2 Indralaya Utara, diperoleh hasil bahwa pembelajaran matematika melalui teknik probing-prompting dapat meningkatkan kemampuan berpikir tingkat tinggi siswa dengan rata-rata $63,8 \%$ yang terkategori baik. Secara rinci terdapat $19 \%$ siswa dengan kategori sangat baik, 38,1\% siswa dengan kategori baik, 28,6\% siswa dengan kategori cukup, 14,3\% siswa dengan kategori kurang, dan tidak ada siswa yang memiliki kemampuan berpikir tingkat tinggi dengan kategori sangat kurang. Kemunculan pada indikator menganalisis sebesar $85,7 \%$, kemunculan pada indikator mengevaluasi sebesar 71,4\%, dan kemunculan indikator mengkreasi sebesar $44,6 \%$.

Saran
Adapun beberapa saran dari peneliti setelah melakukan penelitian ini, yaitu:

1. Bagi guru, saat penerapan pembelajaran melalui teknik pembelajaran probing-prompting harus mampu mengelola kelas dengan baik dan dapat lebih menekankan pada tahap memberikan soal pertanyaan lanjutan dengan level lebih tinggi kepada siswa agar indikator mengkreasi dapat meningkat lebih baik lagi, membiasakan siswa memberikan kesimpulan dari setiap jawaban agar dapat melatih kemampuan berpikir tingkat tinggi siswa pada indikator mengevaluasi, serta lebih banyak memberikan dan membahas soal-soal cerita dan soalsoal bertipe tingkat tinggi dalam pembelajaran.

2. Bagi peneliti lain, agar dapat melakukan penelitian lanjutan menggunakan teknik probingprompting dengan materi yang berbeda.

\section{DAFTAR PUSTAKA}

Arikunto, S. (2010). Prosedur penelitian: Suatu Pendekatan Praktik. (Edisi Revisi). Jakarta: Rineka Cipta

Dewanto. (2014). Meningkatkan kemampuan Berfikir Matematika Tingkat Tinggi Melalui Pembelajaran dengan Pendekatan Induktif-Deduktif: Studi di jurusan matematika FMIPA UNPAD dan FPMIPA UPI. Tesis. Bandung: Pendidikan Matematika (S2), Universitas Pendidikan Indonesia. 
Heong, Y.M., Othman, W.D., Md Yunos, J., Kiong, T.T., Hassan, R., \& Mohamad, M.M. (2011). The Level of Marzano Higher Order Thinking Skills Among Technical Education Students. International Journal of Social and Humanity, 1(2): 121-125.

Krathwohl D.R , \& Anderson. (2002). A revision of bloom's taxonomy: an overview. Theory Into Practice 41(4):212-218.

Permendiknas. (2006). Jurnal Lampiran Peraturan Menteri Pendidikan Nasional No. 22 Tahun 2006 tentang Standar Kompetensi Lulusan Untuk Satuan Pendidikan Dasar dan Menengah.

Rofiah, E., Aminah, N. S., \& Ekawati, E. Y. (2013). Penyusunan Instrumen Tes Kemampuan Berpikir Tingkat Tinggi Fisika Pada Siswa SMP. J. Pend. Fisika. 1(2):17.

Schraw, \& Daniel. (2011). Assessment of Higher Order Thinking Skills. Australia: Information Age Publishing.
Shoimen, A. (2014). Model Pembelajaran Inovatif dalam Kurikulum 2013. Ar-ruzz Media. Yogyakarta.

Suherman, E. (2008). Strategi Pembelajaran Matematika Kontemporer. Bandung: Universitas Pendidikan Indonesia.

Sugiyono. (2013). Metode Penelitian Pendidikan. Bandung: Alfabeta.

Sastrawati, E., Rusdi, M., \& Syamsurizal. (2011). ProblemBased Learning, Strategi Metakognisi, dan Keterampilan Berpikir Tingkat Tinggi Siswa. Tekno-Pedagogi, ISSN 2088205X, 1(2):1-14.

Soegito, E., \& Nurani, Y. (2003). Kemampuan Dasar Mengajar. Jakarta: Universitas Terbuka.

Winarso, W. (2014). Membangun Kemampuan Berfikir Matematika Tingkat Tinggi Melalui Pendekatan Induktif, Deduktif dan Induktif-Deduktif dalam Pembelajaran Matematika. J. Math. Educ., ISSN 2086-3918, 3 (2). 